No $2005-07$

May

Trade Liberalisation, Growth and Poverty in Senegal: A Dynamic Microsimulation CGE Model Analysis

Nabil Annabi, Fatou Cissé, J ohn Cockburn \& Bernard Decaluwé 
Trade Liberalisation, Growth and Poverty in Senegal: A Dynamic Microsimulation CGE Model Analysis

\author{
Nabil Annabi, Fatou Cissé, J ohn Cockburn \\ \& Bernard Decaluwé
}

No $2005-07$

May 


\section{TABLE OF CONTENTS}

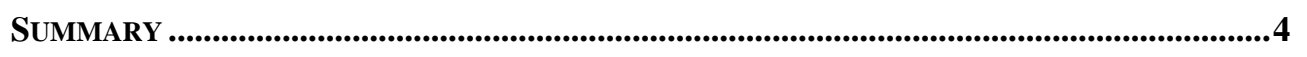

ABSTRACT .............................................................................................................................

RÉSUMÉ .............................................................................................................................

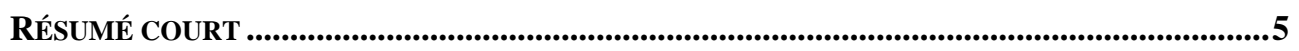

1. INTRODUCTION ..............................................................................................................

2. Overview of trade policy reforms in Senegal ..................................................

3. METHODOLOGY .................................................................................................................

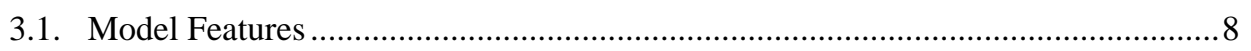

Static module

Dynamic module …………………….........................................................

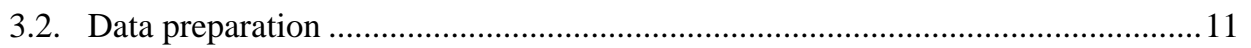

The Social accounting matrix .................................................................................11

The household survey of 1995 (ESAM I)...........................................................12

4. SIMULATION AND RESULTS...........................................................................................13

4.1. Poverty and Inequality in the BaU scenario .........................................................13

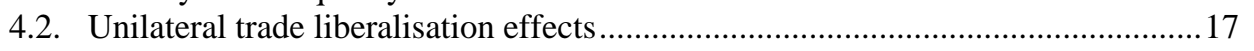

Macro effects .............................................................................................

Sectoral effects ............................................................................................19

Welfare effects ................................................................................................ 20

Poverty and distributional effects .....................................................................2 20

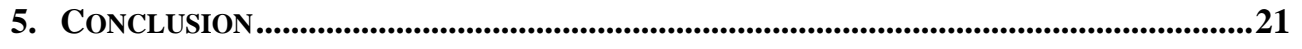

REFERENCES......................................................................................................................24

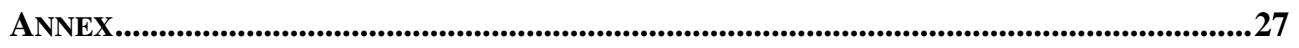

LIST OF WORKING PAPERS RELEASED BY CEPII ..................................................................36 


\title{
TRADE LIBERALISATION, GROWTH AND POVERTY IN SENEGAL: A Dynamic Microsimulation CGE MOdel ANALysis
}

\begin{abstract}
SUMMARY
Much current debate focuses on the role of growth in alleviating poverty. However, the majority of computable general equilibrium (CGE) models used in poverty and inequality analysis are static in nature. The inability of this kind of model to account for growth (accumulation) effects makes them inadequate for long run analysis of the poverty and inequality impacts of economic policies. They exclude accumulation effects and do not allow the study of the transition path of the economy where short run policy impacts are likely to be different from those of the long run. To overcome this limitation we use a sequential dynamic CGE microsimulation model that takes into account accumulation effects and makes it possible to study poverty and inequality through time. Changes in poverty are then decomposed into growth and distribution components in order to examine whether de-protection and factor accumulation are pro-poor or not.
\end{abstract}

The model is applied to Senegalese data using a 1996 social accounting matrix and a 1995 survey of 3278 households. The main findings of this study are that trade liberalisation induces small increases in poverty and inequality in the short run as well as contractions in the initially protected agriculture and industrial sectors. In the long run, it enhances capital accumulation, particularly in the service and industrial sectors, and brings substantial decreases in poverty. However, a decomposition of poverty changes shows that income distribution worsens, with greater gains among urban dwellers and the non-poor.

\footnotetext{
Abstract

An integrated sequential dynamic computable general equilibrium model is used to study the potential poverty and inequality effects of a complete tariff removal in Senegal. The model is calibrated with a 1996 social accounting matrix and a 1995 survey of 3278 households. The outcomes indicate small short run negative impacts in terms of welfare and poverty. In the long run, growth effects captured by the model bring an expansion of the industrial and services sectors and substantial poverty decreases. However, the decomposition of the results shows that the contribution of the redistribution component to poverty alleviation is negative.

Keywords: Dynamic CGE model, trade liberalisation, poverty, inequality, Senegal.

JEL: $\quad$ D33, D58, E27, F17, I32, O15, O55.
} 


\section{LIBÉRALISATION COMMERCIALE, CROISANCE ET PAUVRETÉ AU SÉNÉGAL : UNE ANALYSE PAR MICROSIMULATION EN ÉQUILIBRE GÉNÉRAL DYNAMIQUE}

\section{RÉSUMÉ}

Un grand débat actuel se concentre sur le rôle de la croissance dans l'allégement de la pauvreté. Cependant, la majeure partie des modèles d'équilibre général calculables (MEGC) utilisés dans l'analyse de pauvreté et d'inégalité est de nature statique. Ce type de modèle est inadapté à l'analyse de long terme des impacts des politiques économiques sur la pauvreté et l'inégalité du fait qu'il ne prend pas en compte les effets de croissance (accumulation). De plus, ces modèles statiques ne permettent pas l'étude de la dynamique transitoire où les effets de court terme peuvent être différents de ceux du long terme. Afin de dépasser cette limite, nous proposons d'utiliser un MEGC microsimulé séquentiel pour étudier les effets dynamiques de pauvreté et d'inégalité. Les changements dans les taux de pauvreté peuvent alors être décomposés en effets de croissance et en effets distributifs pour vérifier si la libéralisation commerciale et l'accumulation de facteurs sont pro pauvre ou non.

Le modèle est appliqué au cas sénégalais à l'aide d'une matrice de comptabilité sociale de 1996 et de l'enquête auprès de 3278 ménages de 1995. Les principaux résultats de cette étude montrent que la libéralisation des échanges induit des faibles augmentations de la pauvreté et de l'inégalité à court terme ainsi qu'une contraction des secteurs agricole et industriel initialement protégés. En revanche, dans le long terme la baisse des tarifs douaniers stimule les investissements, en particulier dans les secteurs de l'industrie et des services et entraînement une importante diminution de la pauvreté. Toutefois, la décomposition des changements dans les taux de pauvreté révèle une détérioration de la distribution des revenus avec des gains supérieurs parmi les ménages urbains et les non pauvres.

\section{RÉSUMÉ COURT}

Un modèle d'équilibre général microsimulé dynamique est utilisé pour étudier les effets potentiels de l'élimination complète des tarifs douaniers sur la pauvreté et l'inégalité au Sénégal. Le modèle est calibré à l'aide d'une matrice de comptabilité sociale de 1996 et de l'enquête auprès de 3278 ménages de 1995. Les résultats indiquent une baisse du bien être et une augmentation de la pauvreté à court terme. A long terme, les effets de croissance captés par le modèle entraînent une expansion des secteurs de l'industrie et des services, et une diminution importante de la pauvreté. Toutefois, la décomposition des résultats montre que la contribution de la redistribution à l’allégement de la pauvreté est négative.

Keywords: $\quad$ Dynamic CGE model, trade liberalisation, poverty, inequality, Senegal.

JEL: $\quad$ D33, D58, E27, F17, I32, O15, O55. 


\title{
TRADE LIBERALISATION, GROWTH AND POVERTY IN SENEGAL: A DYNAMIC Microsimulation CGE MODEl ANALysis
}

\author{
Nabil Annabi, Fatou Cissé, John Cockburn and Bernard Decaluwél
}

\section{INTRODUCTION}

Most empirical studies find relatively small welfare and poverty impacts of trade liberalisation. This result is not very surprising as a static framework is generally used in which welfare gains and poverty impacts result solely from a short term reallocation of resources. We contribute to this literature by integrating the growth effects of trade liberalisation and the resulting long-run impacts on welfare and poverty. To do so, we argue that an integrated dynamic microsimulation model is the appropriate instrument.

We apply our framework to the Senegalese economy and we examine the poverty and income distribution effects of a complete trade liberalisation policy. Following Datt and Ravallion (1992) and Kakwani (1997), changes in poverty are decomposed into growth and distribution components in order to examine whether trade liberalisation and factor accumulation are pro-poor or not. The main findings are that trade liberalisation induces small increases in poverty and inequality in the short run as well as contractions in the initially protected agriculture and industrial sectors. In the long run, it enhances capital accumulation, particularly in the service and industrial sectors, and brings substantial decreases in poverty. However, a decomposition of poverty changes shows that income distribution worsens, with greater gains among urban dwellers and the non-poor.

The remainder of this paper is as follows. Sections two presents a brief overview of trade policy in Senegal. Section three describes the data and the model used in this paper. In section four we analyse the potential implications for production, poverty and income distribution of complete trade liberalisation in Senegal. Finally, section five concludes.

\footnotetext{
N. Annabi, J. Cockburn and B. Decaluwé : CIRPEE and PEP, Université Laval, Quebec, Canada. F. Cissé : CRES, Université Cheikh Anta Diop, Dakar, Senegal.

Corresponding author: Nabil Annabi, Pavillon J.A. DeSève, Office 2146, Quebec, Canada G1K 7P4 . Quebec, Canada G1K 7P4

Pavillon J.A. DeSève, Office 2146; nannabi@ecn.ulaval.ca

Notes: We are grateful to the participants at the 3rd Poverty and Economic Policy (PEP) General Meeting in Dakar, the International Conference on Policy Modeling in Paris, the IV workshop on International Economics in Malaga (2004), to L. Alan Winters and Sébastien Jean for their valuable comments. We also thank Abdelkrim Araar and Jean-Yves Duclos for releasing the new DAD software module used in this paper. All errors are our own responsibility.
} 


\section{Overview of trade policy reforms in Senegal}

Trade policy in Senegal had been marked by two main periods. The post-independence import-substitution policy (1960-1980) was based on high tariff rates, export subsidies and the creation of an offshore zone in Dakar in 1974. Although, these measures provided protection to a large number of domestic firms, they had a negative impact on export performance without generating substantial tariff income for the government. These policies were liberalized from 1980 onwards in the context of various structural adjustment programs in the hope of encouraging more efficient resource allocation.

The 100 percent devaluation of the CFA franc in 1994 was an important step in this reform process. Senegal also joined the WTO in 1995 and, following the Uruguay round, consolidated its tariff rates around 30 percent. Quotas have been progressively eliminated and replaced by a temporary surtax on basic goods. In addition, Senegal reduced the level of domestic support to agricultural products. At the regional level, Senegal is a founding member of the Economic Community of Western African States (known as CEDEAO), which has the objective of freer trade at the regional level and the creation of a Common External Tariff (CET). Since 1994 commercial sector liberalisation has been reinforced by Western African Economic and Monetary Union (known as UEMOA) reforms. The objectives of the latter are: the convergence of economic policies and performances of its members; the creation of a customs union; the coordination of sectoral policies regarding the simplification of tariff structures that were enhanced by the approval of the CET in 2000. In 2003, CEDEAO and UEMOA began negotiating a free trade agreement with the European Union. Furthermore, Senegal is negotiating with Tunisia, Morocco and Egypt for new trade agreements in the context of UEMOA.

In spite of the fact that Senegal as a less developed country (LDC) has benefited from access to the European and North American markets for products such as textiles, and its increasing participation in different trade agreements, its exports are not expanding significantly. This appears to be due to high production costs and low product quality that makes Senegalese exports less competitive on the world market. Moreover, the domestic support and subsidies for European farmers and strict European quality norms represent serious restrictions to access.

\footnotetext{
2 Senegal benefits from preferential access under the European "Everything But Arms” (EBA) proposal and of the American "African Growth Opportunity Act” (AGOA), which offer duty-free access for all products of the generalised system of preferences (GSP) including textile and clothing. In addition, since 2003 Senegal has benefited from the Canadian initiative of eliminating duties and quotas on most imports from LDCs.
} 


\section{Methodology}

To assess the potential effects of trade liberalisation on production, poverty and inequality in Senegal, we develop a sequential dynamic microsimulation CGE model. In combining the growth aspects of a dynamic CGE model with the detailed information provided by microsimulation techniques, we are in a position to adequately measure the poverty impacts of trade liberalisation. We follow the integrated microsimulation approach developed recently by Decaluwé et al. (1999), Cockburn (2001) and Cogneau and Robillard (2001) 3 The dynamic CGE model is calibrated using a social accounting matrix for the year 1996 and the 1995 Senegalese Household Expenditure Survey (ESAM I). In using the integrated microsimulation approach we are able to take into account household heterogeneity in terms of income sources (notably factor endowments) and consumption patterns. In the following sections we briefly describe the model and the data used.

\subsection{Model Features}

Dynamic general equilibrium models can be classified as intertemporal or sequential (recursive). Intertemporal dynamic models are based on optimal growth theory where the behaviour of economic agents is characterized by perfect foresight. In a number of circumstances, and particularly in a developing country, it is hard to assume that agents have perfect foresight. For this reason we believe that it is much more appropriate to develop a sequential dynamic CGE model. In this kind of dynamics the agents have myopic behaviour. A sequential dynamic model is basically a series of static CGE models that are linked between periods by behavioural equations for endogeneous variables and by updating procedures for exogenous variables. Capital stock is updated endogenously with a capital accumulation equation, whereas population (and total labour supply) is updated exogenously between periods. It is also possible to add updating mechanisms for other variables such as public expenditure, transfers, technological change or debt accumulation. Below we present a brief description of the static and dynamic aspects of the model. A complete list of equations and variables is presented in the annex.

\section{Static module}

Activities. On the production side we assume that in each sector there is a representative firm that generates value added by combining labour and capital. We adopt a nested structure for production. Sectoral output is a Leontief function of value added and total intermediate consumption. Value added is in turn represented by a CES function of labour and capital in the non-agricultural sectors (industry and services), and a CES function of land and a composite factor in agriculture. The latter is also represented by a CES function of primary factors: agricultural capital and labour. Value added in the public sector is generated by labour alone. Labour is assumed to be fully mobile in the model.

\footnotetext{
${ }^{3}$ For a review on microsimulation techniques see Davies (2003).
} 
Households. They earn their income from production factors: labour, land and capital. They also receive dividends, intra-household transfers, government transfers and remittances. They pay direct income tax to the government. Household savings are a fixed proportion of total disposable income. Household demand is derived from a C-D utility function. The model includes 3278 households from the household survey.

Firms. There is one representative firm which earns capital income, pays dividends to households and foreigners and pays direct income taxes to the government.

Foreign Trade. We assume that foreign and domestic goods are imperfect substitutes. This geographical differentiation is introduced by the standard Armington assumption with a constant elasticity of substitution function (CES) between imports and domestic goods. On the supply side, producers make an optimal distribution of their production between exports and domestic sales according to a constant elasticity of transformation (CET) function. Furthermore, we assume a finite elasticity export demand function ${ }^{4}$. Even if we assume that international terms of trade are given we reject the small country assumption for Senegal and assume that foreign demand for Senegalese exports is less than infinite. In order to increase their exports, local producers must decrease their free on board (FOB) prices.

Government. The government receives direct tax revenue from households and firms and indirect tax revenue on domestic and imported goods. Its expenditure is allocated between the consumption of goods and services (including public wages) and transfers. The model accounts for indirect or direct tax compensation in the case of a tariff cut.

Equilibrium. General equilibrium is defined by the equality (in each period) between supply and demand of goods and factors, and the investment-saving identity.

\section{Dynamic module}

Capital accumulation. In every period the capital stock $(K D)$ is updated with a capital accumulation equation involving the rate of depreciation $(\delta)$ and investment (Ind):

$$
K D_{t r, t+1}=(1-\delta) K D_{t r, t}+\operatorname{Ind} d_{t r, t}
$$

This equation describes the law of motion for the sectoral capital stock. It assumes that stocks are measured at the beginning of the period and that the flows are measured at the end of the period.

${ }^{4}$ The long run export demand elasticity is assumed equal to ten. 
Investment demand. This function determines how new investment will be distributed between the different sectors. This can also be done through a capital distribution function ${ }^{5}$. The investment demand function we use here is similar to those proposed by Bourguignon et al. (1989), and Jung and Thorbecke (2003). The capital accumulation rate - ratio of investment $(I n d)$ to capital stock $(K D)$ - is increasing with respect to the ratio of the rate of return to capital $(R)$ and its user $\operatorname{cost}(U)$ :

$$
\frac{I n d_{t r, t}}{K D_{t r, t}}=\phi_{t r} \cdot\left(\frac{R_{t r, t}}{U_{t}}\right)^{2}
$$

The latter is equal to the dual price of investment (Pinv) times the sum of the depreciation rate and the exogenous real interest rate (ir):

$$
U_{t}=\operatorname{Pinv}_{t} \cdot(i r+\delta)
$$

The elasticity of the rate of investment with respect to the ratio of return to capital and its user cost is assumed to be equal to two. By introducing investment by destination, we respect the equality condition with total investment by origin in the SAM. Besides, investment by destination is used to calibrate the sectoral capital stock in the base run.

Labour supply growth. Total labour supply is an endogenous variable, although it is assumed to simply increase at the exogenous population growth rate. Note that all interagent transfers in the model increase at the same rate.

The exogenous dynamic updating of the model includes nominal variables (that are indexed) like transfers and volumes like world demand for Senegalese exports. The model is formulated as a static model that is solved recursively over a 20 period time horizon ${ }^{7}$. The model is homogenous in prices and the nominal exchange rate is the numéraire in each period.

\footnotetext{
5 Abbink, Braber and Cohen (1995), use a sequential dynamic CGE model for Indonesia where total investment is distributed with a function of base year sectoral shares in total capital remuneration and sectoral profit rates.

More details on the introduction of sequential dynamics and calibration can be found in Annabi et al. (2004).

${ }^{7}$ The model is formulated as a system of non linear equations solved recursively as a constrained non-linear system (CNS) with GAMS/Conopt3 solver.
} 
Trade Liberalisation, Growth and Poverty in Senegal

\subsection{Data preparation}

\section{The Social accounting matrix}

The base run structure of the Senegalese economy is represented by the 1996 SAM (Table 1). The economy is represented by three tradable sectors, agriculture, industry (including agro-industry) and services, and the non-tradable public service sector. Table 1 indicates that only the agricultural and industrial sectors are protected and that the tariff rates are higher for the latter. Import intensities and shares are also highest in the industrial sector. Industry contributes 45.7 and 25.8 percent, respectively, of total production and value added. Moreover, industrial exports represent 73.3 percent of national exports. The service sector's export share is 26.1 percent and it has the highest share in value added (47 percent). It employs 48.3 percent of workers and uses half the national capital stock.

Table 1: Base run statistics

\begin{tabular}{l|l|cccc|c}
\hline & & Agriculture & Industry & Services & $\begin{array}{c}\text { Public } \\
\text { services }\end{array}$ & Total \\
\hline Tariff rate & tm* & 13.6 & 20.7 & & & \\
Import intensity & M/Q & 16.5 & 30.8 & 11.8 & & \\
Import share & Mi/M & 14.0 & 69.8 & 16.2 & & 100 \\
Export Intensity & EXi/Xi & 0.6 & 23.2 & 12.0 & & \\
Export share & EXi/EX & 0.7 & 73.3 & 26.1 & & 100 \\
Value added share & VAi/VA & 19.4 & 25.8 & 47.0 & 7.7 & 100 \\
Value added rate & VAi/XSi & 51.7 & 24.8 & 65.4 & 54.2 & \\
Intermediate Demand & DIi/Qi & 33.2 & 48.8 & 75.3 & & \\
Production share & XSi/XS & 16.5 & 45.7 & 31.5 & 6.2 & 100 \\
Stock of capital share & KDi/KD & 12.5 & 37.4 & 50.1 & & 100 \\
Labour share & LDi/LD & 18.2 & 21.1 & 48.3 & 12.4 & 100 \\
\hline Value added composition & \multicolumn{7}{|l|}{5} & & & & \\
\hline Labour share & LDi/VAi & 58.1 & 50.6 & 63.6 & 100.0 & \\
Capital share & KDi/VAi & 22.0 & 49.4 & 36.4 & & \\
Land share & Land/VAi & 19.9 & & & & \\
\hline Total & \multicolumn{7}{|l|}{100} & 100 & 100 & 100 & \\
\hline
\end{tabular}

Source: Authors’ calculations based on 1996 SAM.

* See the annex for the glossary.

The composition of value added presented in the bottom of the table suggests that industry and services are more capital intensive than agriculture and that public service value added is generated only by labour. Given these characteristics we expect that tariff removal will benefit more the non-protected services sector, which is likely to attract factors of production and expand its production. Finally, we note that accumulation effects present in the model will be decisive for long run impacts. 


\section{The household survey of 1995 (ESAM I)}

The examination of the household survey (HS) data suggests an underevaluation of expenditure and, especially, income with respect to national data represented by the SAM. As a result, the HS shows negative savings for more than 75 percent of households. The literature on data reconciliation offers different alternatives. We may keep the structure of the SAM and adjust the household survey. This method has the advantage to save the structure of the economy but it is likely to change the structure of income and expenditure in the household survey. The other alternative is to adjust the SAM to meet the totals of the household survey. In the present research we use an intermediate approach.

In order to keep the initial structure of consumption we maintain the expenditure vectors from the household survey and adjust the exogenous stock variation account in the SAM. This method makes it possible to conserve the initial consumption structure and the original rates of poverty and inequality. With regards to income, we adjust the household survey to meet the national data based on the SAM. However, we make some adjustments in income beforehand. The income adjustment concerns transfers and factor remunerations:

- The HS does not include information on capital remuneration. The latter is considered as residual and was estimated using the self employed labour income and rent from land.

- The value of transfers in the HS is smaller than total transfers in the SAM. We assume that the received transfers are underevaluated. We consider that the transfers from the firms to households are equal to dividends, and that government transfers are represented by public allowances. Intra household transfers were estimated using data on remittances assuming that for each household the amount of transfer payments is equal to its share in total received transfers.

- Finally the totals of incomes from the SAM were distributed using the shares of endowments in the adjusted HS. Given the adjustment in income vectors we find that the differences between the two sources become small and the structure is practically unchanged.

Table 2 presents household income composition based on the household survey. It shows that factor income represents the largest source of income for both urban and rural households. Labour income represents 64.9 and 58.2 percent of total urban and rural household income, respectively. Capital income comes second for urban households, representing 19.9 percent of total income. Land and capital are primary sources of income for rural households. They receive almost all the returns to land (97 percent) and capital represents 15.2 percent of their income. The other sources of income are dividends and various transfers but these are fixed or updated exogenously for all households. Given these substantial differences in income sources, we may expect that trade liberalisation will have different income effects depending on how factor remunerations are affected.

${ }^{8}$ Enquête Sénégalaise Auprès des Ménages (ESAM). 
Table 2: Households' income composition

\begin{tabular}{l|cc}
\hline & Urban & Rural \\
\hline Proportion (percent) & 39 & 61 \\
\hline Labour & 64.9 & 58.2 \\
& $(81.3)^{*}$ & $(18.7)$ \\
Capital & 19.9 & 15.2 \\
& $(45.2)$ & $(8.8)$ \\
Land & 0.1 & 18.8 \\
& $(3.0)$ & $(97.0)$ \\
Dividends & 9.3 & 0.0 \\
Other income & 5.7 & 7.8 \\
\hline Total & 100 & 100 \\
\hline
\end{tabular}

Source: Authors' calculations based on the ESAM I 1995.

* Figures in brackets represent shares in factor income.

\section{SIMULATION AND RESULTS}

In this section we simulate a complete unilateral trade liberalisation policy, discuss the macro and sectoral effects, and analyze their implications for poverty and inequality in Senegal. In this simulation government budget equilibrium is met through a neutral indirect tax adjustment. Saving-Investment equilibrium is met with an adjustment variable introduced in the investment demand function.

In static CGE models, counterfactual analysis is made with respect to the base run that is represented by the initial SAM. However, in dynamic models the economy grows even without a policy shock and the analysis should be done with respect to the growth path in the absence of any shock. Sectoral and macro effects are presented in table 5 and poverty and inequality effects are depicted in table 6 . These tables report the percentage variation between the $\mathrm{BaU}$ path and the after simulation path for each variable. But beforehand we should examine the evolution of poverty and inequality along the $\mathrm{BaU}$ path.

\subsection{Poverty and Inequality in the BaU scenario}

Poverty and inequality levels on the BaU path (for base run, year 1996, and 2015) are reported in table 3 . $^{9}$ We note that poverty is initially more concentrated among rural

9 We use Foster, Greer and Thorbecke (1984) class of poverty measures: $P_{\alpha}=\frac{1}{n} \cdot \sum_{i=1}^{p}\left[\left(z-y_{i}\right) / z\right]^{\alpha}$ where $y_{i}$ : income $; z$ : poverty line; $n$ : population size (total number of households); $p$ : number of poor households; $i$ : number of household with income below the poverty line. If $\alpha=0$ : poverty incidence (or headcount ratio) is given by the proportion of the population who are poor. If $\alpha=1$ : poverty gap index (poverty depth) given by the aggregate income shortfall of the poor as proportion of the poverty line and 
households. However, income distribution is more unequal in urban areas. Total inequality, measured by the Gini coefficient, is equal to 41.41 percent. The path generated by a recursive expansion of the economy shows that accumulation effects captured by our model contribute to a substantial decrease in poverty. Nonetheless, income distribution has worsened and inequality has increased particularly among urban households. At the national level the Gini coefficient is equal to 53.95 percent in the long run.

Table 3: BaU Scenario poverty and inequality

\begin{tabular}{l|cccc|cc}
\hline & \multicolumn{2}{|c}{ Urban } & \multicolumn{2}{c|}{ Rural } & \multicolumn{2}{c}{ All } \\
\hline & $\mathbf{1 9 9 6}$ & $\mathbf{2 0 1 5}$ & $\mathbf{1 9 9 6}$ & $\mathbf{2 0 1 5}$ & $\mathbf{1 9 9 6}$ & $\mathbf{2 0 1 5}$ \\
\hline Headcount ratio & 37.74 & 13.22 & 88.99 & 73.45 & 69.00 & 49.96 \\
Poverty gap & 9.05 & 2.55 & 40.38 & 26.66 & 28.16 & 17.26 \\
Poverty severity & 3.07 & 0.77 & 21.98 & 12.45 & 14.60 & 7.89 \\
Gini & 38.30 & 52.06 & 29.49 & 32.09 & 41.41 & 53.95 \\
\hline
\end{tabular}

Source: Authors’ calculations.

In order to understand the factors behind these changes and to determine their respective contributions we follow the approach developed by Datt and Ravallion (1992). ${ }^{10}$ According to these authors, changes in poverty measures can be decomposed into growth and distribution components. We assume a poverty measure $P_{t}=P\left(z / \mu_{t}, L_{t}\right)$ where $z$ is the poverty line, $\mu_{t}$ is the mean income and $L_{t}$ is a vector of parameters describing the Lorenz curve at date $t$. The level of poverty may change due to a change in the mean income $\mu_{t}$ relative to the poverty line or to a change in relative inequalities $L_{t}$. The growth component of change in poverty is defined as the change in poverty due to a change in the mean income while holding the Lorenz curve constant at some reference level $L_{r}$. The distribution component is the change in poverty due to a change in the Lorenz curve while keeping the mean income constant at the reference level $\mu_{r}$. Change in poverty over dates $t$ and $t+n$ can then be decomposed as follows:

$$
\begin{array}{llcc}
P_{t+n}-P_{t}=G(t, t+n ; r)+ & D(t, t+n ; r)+R(t, t+n ; r) \\
\begin{array}{l}
\text { change in } \\
\text { poverty }
\end{array} & \begin{array}{l}
\text { growth } \\
\text { component }
\end{array} & \begin{array}{l}
\text { redistribution } \\
\text { component }
\end{array} & \text { residual }
\end{array}
$$

where growth and distribution components are given by:

$$
G(t, t+n ; r) \equiv P\left(z / \mu_{t+n}, L_{r}\right)-P\left(z / \mu_{t}, L_{r}\right)
$$

normalized by the population size. If $\alpha=2$ : squared poverty gap index or the severity of poverty measure is based on the sum of squared proportionate poverty deficits.

${ }^{10}$ See Boccanfuso and Kaboré (2003) for an application of the decomposition approach to Burkina Faso and Senegal. 


$$
D(t, t+n ; r) \equiv P\left(z / \mu_{r}, L_{t+n}\right)-P\left(z / \mu_{r}, L_{t}\right)
$$

for $r=t$, the residual can be written:

$$
\begin{aligned}
R(t, t+n ; t) & =G(t, t+n ; t+n)-G(t, t+n ; t) \\
& =D(t, t+n ; t+n)-D(t, t+n ; t)
\end{aligned}
$$

This residual is the difference between the growth (distribution) components evaluated at the terminal and initial Lorenz curves (mean incomes) respectively. The residual disappears if $\mu_{t}$ or $L_{t}$ remains constant or if we estimate the average of the components obtained using the initial and final years as the reference. Kakwani (1997) uses this latter approach and defines the average growth and inequality effects as:

$$
\begin{aligned}
& \hat{G}(t, t+n)=\frac{1}{2}\left[P\left(z, \mu_{t+n}, L_{t}\right)-P\left(z, \mu_{t}, L_{t}\right)+P\left(z, \mu_{t+n}, L_{t+n}\right)-P\left(z, \mu_{t}, L_{t+n}\right)\right] \\
& \hat{D}(t, t+n)=\frac{1}{2}\left[P\left(z, \mu_{t}, L_{t+n}\right)-P\left(z, \mu_{t}, L_{t}\right)+P\left(z, \mu_{t+n}, L_{t+n}\right)-P\left(z, \mu_{t+n}, L_{t}\right)\right]
\end{aligned}
$$

Changes in poverty can then be decomposed as:

$$
\begin{array}{lcc}
P_{t+n}-P_{t}=\hat{G}(t, t+n)+ & \hat{D}(t, t+n) \\
\begin{array}{l}
\text { change in } \\
\text { poverty }
\end{array} & \begin{array}{l}
\text { growth } \\
\text { component }
\end{array} & \begin{array}{l}
\text { redistribution } \\
\text { component }
\end{array}
\end{array}
$$

Decomposition results are presented in figures $1 \mathrm{a}$ and $1 \mathrm{~b}$, and table 4 . They suggest that growth component played a major role in poverty reduction and that distribution had a negative impact on the poor. Figure 1a depicts the decomposition for a wide range of poverty lines. It shows that growth reduces poverty and that its contribution is the highest among households clustered about the base run poverty line. However, distribution component is negative for low levels of poverty line and positive for high levels of poverty line. This may be explained by the fact that when we move to the right assuming high levels of poverty line we take into account non poor households which benefited more from factor accumulation. Table 4 presents the decomposition results assuming the base run poverty line. ${ }^{11}$ The figures confirm that growth component, for both Datt and Ravallion and Kakwani decomposition approaches, played the main role in reducing poverty along the BaU path.

${ }^{11}$ The second set of lines in this table will be discussed in the next section. 
Figure 1a: Poverty change decomposition

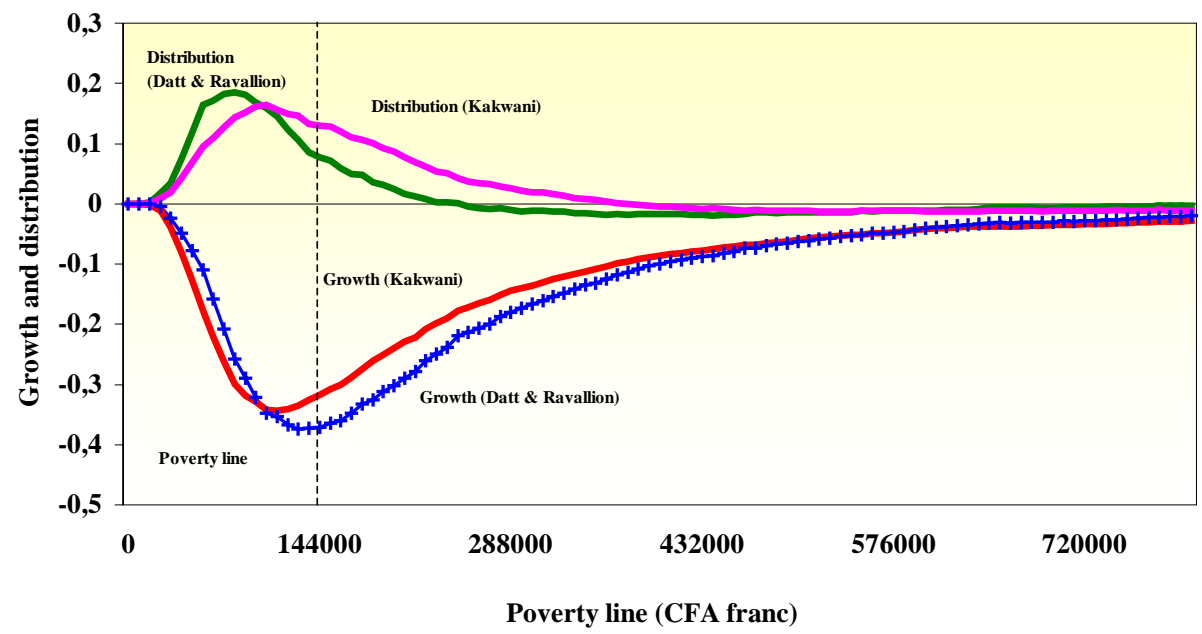

Figure 1b: Growth and distribution components of poverty changes given the baseline poverty line

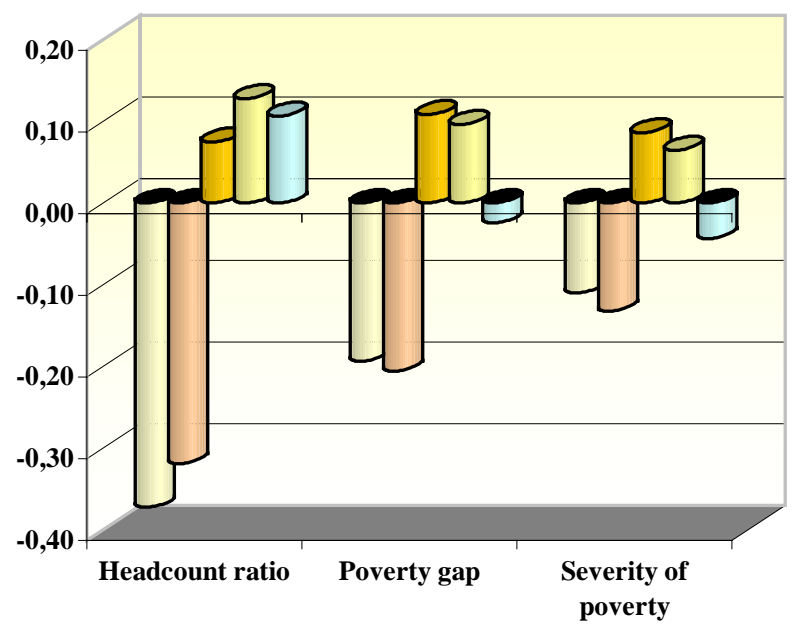

$\square$ Growth component (DR)

$\square$ Growth component (K)

$\square$ Redistribution (DR)

口Redistribution (K)

口Residual 
Trade Liberalisation, Growth and Poverty in Senegal

Table 4: Decomposition of the $\mathrm{BaU}$ and simulation paths poverty changes.

\begin{tabular}{ll|c|c|c|c|c|c}
\hline & $\begin{array}{c}\text { Growth } \\
\text { component } \\
\text { (Datt \& } \\
\text { Ravallion) }\end{array}$ & $\begin{array}{c}\text { Growth } \\
\text { component } \\
\text { (Kakwani) }\end{array}$ & $\begin{array}{c}\text { Distribution } \\
\text { component } \\
\text { (Datt \& } \\
\text { Ravallion) }\end{array}$ & $\begin{array}{c}\text { Distribution } \\
\text { component } \\
\text { (Kakwani) }\end{array}$ & $\begin{array}{c}\text { Residual } \\
\text { (Datt \& } \\
\text { Ravallion) }\end{array}$ & Difference \\
\hline \multirow{2}{*}{$\mathrm{BaU}^{\mathrm{a}}$} & Headcount ratio & -37.2 & -31.9 & 7.5 & 12.8 & 10.7 & -19.0 \\
& Poverty gap & -19.3 & -20.5 & 10.9 & 9.6 & -2.4 & -10.9 \\
\hline \multirow{3}{*}{$\mathrm{SIM}$} & Poverty severity & -11.0 & -13.2 & 8.6 & 6.5 & -4.3 & -6.7 \\
\hline & Headcount ratio & -39.1 & -33.4 & 7.7 & 13.3 & 11.3 & -20.1 \\
& Poverty gap & -20.1 & -21.5 & 11.4 & 10.0 & -2.7 & -11.4 \\
& Poverty severity & -11.4 & -13.8 & 9.2 & 6.8 & -4.8 & -7.0 \\
\hline
\end{tabular}

Source: Authors’ calculations.

a: BaU refers to 1996-2015 poverty change decomposition on the BaU path and SIM is 1996-2015 poverty change decomposition on the simulation path.

b: The difference corresponds to the changes in poverty reported in table 3 .

\subsection{Unilateral trade liberalisation effects}

The main determinants of trade liberalisation effects are the values of trade elasticities, the share of imports and exports, the cost of inputs, and the general equilibrium effects of supply and demand. The elimination of domestic distortions caused by the tariffs leads to more efficient factor reallocation between sectors to the benefit of the initially less protected sectors. Tariff elimination reduces import prices, which leads to an increase in import demand and a decrease in domestic sales. The change in domestic good demand influences their prices and their supply. Besides, these price changes affect the composite good price, factor demands and remunerations, and the value added price. As mentioned above, the resulting traditional effect is an expansion of the less protected and export oriented sectors. However, since our model is dynamic it takes into account not only the efficiency effects but also the accumulation effects. These effects are driven by two main factors the disposable savings and the profitability of investing. The former is linked to the distribution of income in favour of agents with higher propensity to save and the latter is linked to the capital good price. We pay special attention to these elements in our simulation analysis. 
Table 5: Macro and sectoral effects (percent change from BaU path)

\begin{tabular}{|c|c|c|c|c|c|c|c|c|}
\hline \multirow[b]{2}{*}{ Sectoral results } & \multicolumn{2}{|c|}{ Agriculture } & \multicolumn{2}{|c|}{ Industry } & \multicolumn{2}{|c|}{ Services } & \multicolumn{2}{|c|}{ Public services } \\
\hline & 1996 & 2015 & 1996 & 2015 & 1996 & 2015 & 1996 & 2015 \\
\hline Import price & -11.93 & -11.93 & -17.17 & -17.17 & 0.00 & 0.00 & & \\
\hline Domestic price & -6.17 & -4.46 & -8.02 & -8.14 & -5.74 & -6.66 & & \\
\hline Composite price & -4.29 & -2.92 & -8.25 & -8.42 & -2.16 & -3.11 & & \\
\hline FOB export price & -0.75 & -0.63 & -1.00 & -1.32 & -1.04 & -1.39 & & \\
\hline Producer price & -6.14 & -4.44 & -6.30 & -6.39 & -5.15 & -5.94 & -5.70 & -4.13 \\
\hline Value added price & -9.08 & -5.45 & -7.73 & -7.26 & -5.28 & -6.21 & -6.60 & -2.82 \\
\hline$\underline{\text { Rate of return to capital }}$ & -13.55 & -10.78 & -8.89 & -11.27 & -2.93 & -11.46 & & \\
\hline Imports & 6.03 & 11.23 & 11.58 & 15.47 & -7.84 & -7.05 & & \\
\hline Domestic good & -3.59 & -1.55 & -4.62 & -1.12 & 0.70 & 3.07 & & \\
\hline Composite good & -2.04 & 0.42 & 0.19 & 3.80 & -0.33 & 1.85 & & \\
\hline Exports & 7.86 & 6.51 & 10.52 & 14.13 & 11.00 & 15.03 & & \\
\hline Production & -3.52 & -1.49 & -1.00 & 2.69 & 1.96 & 4.66 & 0.00 & 0.00 \\
\hline Investment (destination) & -5.17 & 14.05 & 5.25 & 16.57 & 19.41 & 19.57 & 0.00 & 0.00 \\
\hline Capital stock (SR=1997) & -0.39 & 3.03 & 0.39 & 6.39 & 1.46 & 9.58 & & \\
\hline Labour demand & -5.97 & -3.82 & -1.97 & -1.09 & 3.11 & 1.71 & 0.00 & 0.00 \\
\hline Investment (origin) & -4.39 & -1.64 & -0.27 & 4.27 & -6.48 & -1.44 & & \\
\hline Intermediate demand & -1.30 & 1.88 & -0.46 & 2.84 & -0.86 & 1.94 & & \\
\hline Private consumption & -2.24 & 0.18 & 2.35 & 6.90 & -3.89 & 1.17 & & \\
\hline Macro results & 1996 & 2015 & & & & & & \\
\hline Real GDP & -0.02 & 2.62 & & & & & & \\
\hline Welfare $(\mathrm{EV})^{*}$ & -0.26 & 1.69 & & & & & & \\
\hline Poverty level & 0.17 & -2.04 & & & & & & \\
\hline Wage rate & -6.59 & -2.80 & & & & & & \\
\hline Rate of return to land & -11.23 & -6.39 & & & & & & \\
\hline CPI & -5.60 & -5.50 & & & & & & \\
\hline Capital good price & -9.70 & -8.88 & & & & & & \\
\hline
\end{tabular}

Source: Authors’ calculations.

*: Equivalent variation in percentage of base income.

\section{Macro effects}

On the aggregate level, unilateral trade liberalisation has negative impacts in the short run. Real GDP and welfare decreases by 0.02 and 0.26 percent, respectively. In addition the results indicate an increase in the head-count ratio by 0.17 percent. However, in the long run and due to the presence of accumulation effects we observe that Real GDP increases by 2.26 percent and welfare improves by 1.69 percent. Besides, the combined income and price effects lead to a decline in poverty by 2.04 percent. These results confirm the fact that through the availability of cheaper investment goods and hence an enhanced capital 
accumulation, trade liberalisation effects are adequately captured in a dynamic framework. Furthermore, the short run negative impacts are resulting from the fact that capital is sector specific during the first period and adjusts only in the subsequent periods. These negative impacts disappear when factors are reallocated to the most expanding sectors. In order to understand the mechanisms through which tariff removal has led to the above-mentioned short run and long run changes we examine in what follows the sectoral results.

\section{Sectoral effects}

The shock of tariff elimination leads first to a decrease in the domestic price of imports. We find that the greatest reduction is in the industrial sector, which had high initial tariff rates (see table 1). The fall in domestic prices and initial import penetration ratios will influence the sectoral import demand changes. The effect on the latter is consistent with our expectations. The service sector registers negative import growth in both the short and the long runs due to unchanged import prices (this sector is initially unprotected) and the decrease in domestic prices that make local purchases more attractive. Furthermore, we note a decline in domestic good demand in agriculture and industry in the short run. In the long run, though less pronounced, this trend is maintained and the service sector attains higher positive growth in domestic demand. The service sector expands and the importcompeting and (previously) protected sectors contract in the short run. In the long run, the agricultural sector continues declining and the service and industrial sectors expand.

We recall the assumption that the current account balance is fixed. Because of this closure rule, the increase in imports should be compensated by an increase in exports. With a negative sloping demand curve for exports the FOB export price should decrease to attain that objective. As a result we observe that the FOB export prices decrease in all sectors and particularly in the service sector. This suggests that this sector becomes more competitive in the long run due to trade liberalisation. The expansion of exports is explained by the increase in relative price of exports.

As we mentioned above, the efficiency (reallocation) and accumulation effects will determine the impact on production. Both effects are driven, in large extent, by value added price, factor remunerations and the cost of inputs represented by the composite price. The latter decreases in all the sectors in both the short and the long runs. The reallocation effects among the sectors are determined by the change in value-added price. The results indicate that resources will move towards the service sector in the short run. Variations in value added prices influence the capital rental rate and labour wage rates.

It is important to recall that labour is mobile across sectors in both the short and the long runs, whereas capital is mobile only after the first year and through new investments. In the short run, labour moves to the expanding service sector. In the long run the pattern of changes is almost the same and the service sector absorbs most of the labour force. Along with the decrease in value added prices and wage rates, capital rental rates decrease in almost all the sectors. However, they decrease relatively less than capital user costs in both industry and services, which attract more investment in both the short and the long runs. 
These changes in investment demand influence sectoral capital accumulation. In the long run, the capital stock increases more for the service sector followed by the industry and the agricultural sectors. Finally, the general effect suggests that the highly protected and import-competing sectors contract. However, in the long run the industrial sector succeeds in attracting more investment and therefore in increasing its output.

\section{Welfare effects}

Regarding the impacts on household welfare, results are reported in table 6. As factor remuneration represents the main income source for households, we observe an overall decrease in income. However, rural households are more affected than urban households. This result is explained by high rural household endowments in land (see table 2) and the decline of the agricultural sector. In the short run, total income decreases more than CPI leading to a decline in real consumption and welfare in both urban and rural areas. In the long run, the combined income and price effects lead to positive variations in real consumption and welfare. The equivalent variation increases by 1.81 and 1.27 percent for urban and rural households respectively.

Table 6: Impact on households (percent change from BaU path)

\begin{tabular}{l|cc|cc|cc}
\hline & \multicolumn{2}{|c|}{ Urban } & \multicolumn{2}{c|}{ Rural } & \multicolumn{2}{c}{ All } \\
\cline { 2 - 7 } & $\mathbf{1 9 9 6}$ & $\mathbf{2 0 1 5}$ & $\mathbf{1 9 9 6}$ & $\mathbf{2 0 1 5}$ & $\mathbf{1 9 9 6}$ & $\mathbf{2 0 1 5}$ \\
\hline Income & -6.39 & -4.07 & -6.90 & -4.32 & -6.50 & -4.13 \\
$\quad$ Capital income & -6.48 & -4.52 & -6.49 & -4.51 & -6.49 & -4.52 \\
Labour income & -6.59 & -2.80 & -6.59 & -2.80 & -6.59 & -2.80 \\
Land income & -11.28 & -6.45 & -11.23 & -6.39 & -11.23 & -6.39 \\
\hline Real consumption & -0.05 & 4.05 & -1.43 & 2.03 & -0.58 & 3.45 \\
Welfare (EV) & -0.08 & 1.81 & -0.93 & 1.27 & -0.26 & 1.69 \\
\hline Headcount ratio & 0.16 & -7.41 & 0.17 & -1.42 & 0.17 & -2.04 \\
Poverty gap & 0.66 & -7.06 & 1.93 & -2.66 & 1.78 & -2.95 \\
Poverty severity & 0.98 & -7.79 & 2.96 & -3.61 & 2.81 & -3.68 \\
Inequality (Gini) & 0.10 & 0.67 & 0.71 & 0.84 & 0.77 & 1.02 \\
\hline
\end{tabular}

Source: Authors' calculations.

\section{Poverty and distributional effects}

The changes in the three measures of poverty are in line with the changes in welfare and real consumption. In the short run, the three measures of poverty increase more for rural households than for urban households. In the long run, trade liberalisation and accumulation effects lead to a significant decrease in poverty; however they benefit more the urban households. The head-count ratio decreases by 7.41 and 1.42 percent among urban and rural dwellers respectively. Moreover, we observe a higher increase in inequality among rural households. In the long run, the Gini coefficient increases by 0.84 and 
0.67 percent for rural and urban areas, respectively. However, these changes are less important among rural households because of the lower initial level of inequality (32.09 percent in rural area against 52.06 percent in urban area).

At the national level, the decomposition of the results reported in table 4 indicates that, in the current simulation, growth and redistribution components are larger than on the $\mathrm{BaU}$ path. The final effect is a decrease in overall poverty head-count, depth and severity. Furthermore, poverty dominance analysis confirms for a wide range of poverty lines that long run accumulation effects are enhanced by trade liberalisation, leading to significant poverty relief (see figures 2-4).

Finally, figure 5 presents the income growth curves in both urban and rural area (Ravallion and Chen 2003). On the vertical axis it plots the percentage variation in income. On the horizontal axis it plots the households ranked by percentiles of income. We observe that the income gains are more equal in rural areas than in urban areas. In the latter, it is obvious that tariff removal and accumulation effects benefit the non-poor households more.

\section{CONCLUSION}

In this paper we develop an integrated dynamic microsimulation CGE model to analyze the potential poverty and inequality effects of complete and unilateral trade liberalisation in Senegal. The model uses a 1996 social accounting matrix and a 1995 survey of 3278 households. We argue that the proposed approach is very promising since it allows the short and the long runs analysis of the linkages between trade liberalisation, growth (accumulation) income distribution and poverty.

The main findings of this study are that full tariff removal in Senegal leads to a small increase in poverty and inequality in the short run, as well as contractions in the initially protected agriculture and industrial sectors. In the long run, trade liberalisation enhances capital accumulation, particularly in the service and industrial sectors, and brings substantial increases in welfare and decreases in poverty. However, a decomposition of poverty changes shows that income distribution worsens, with greater gains among urban dwellers and the non-poor. 

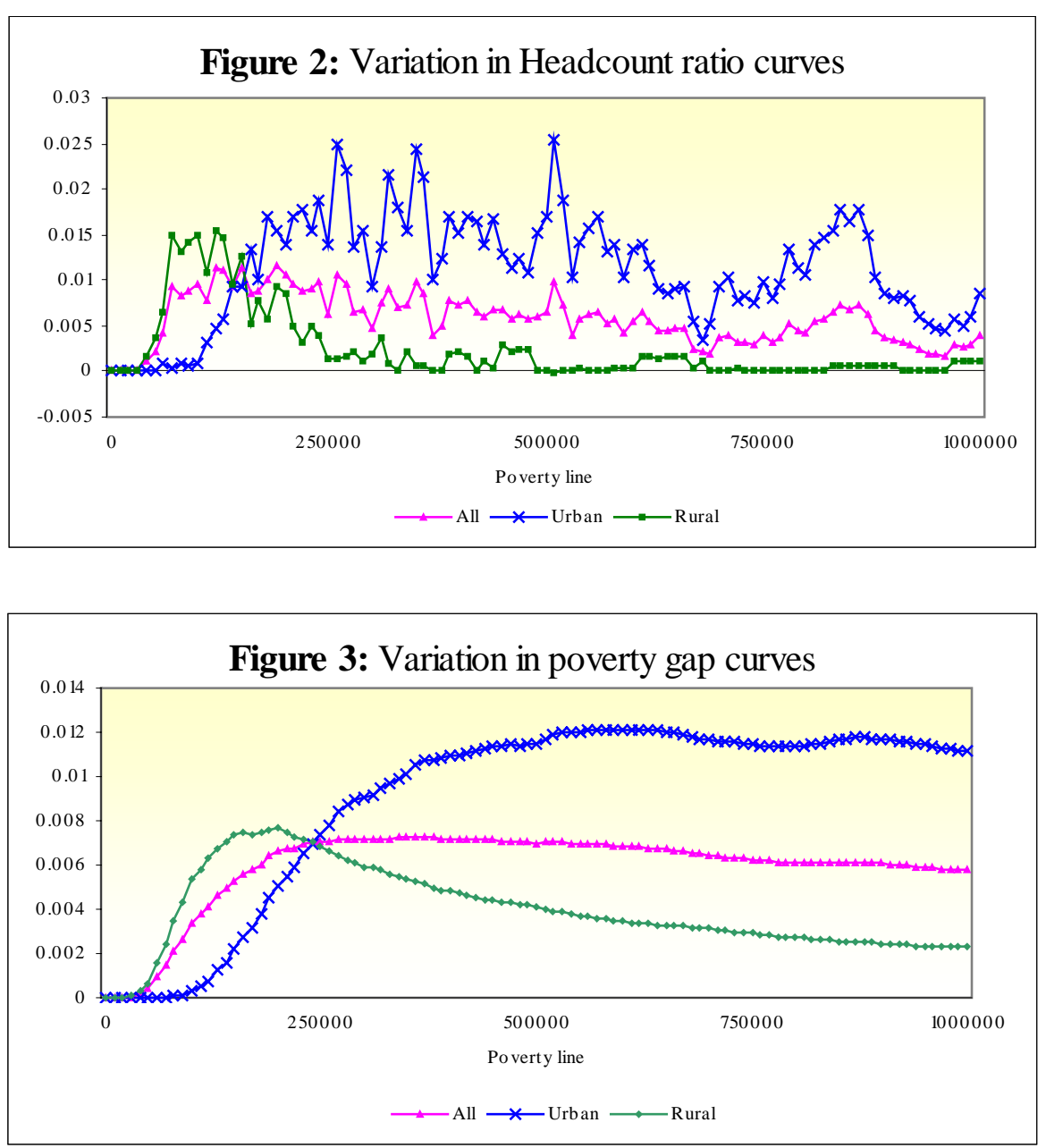

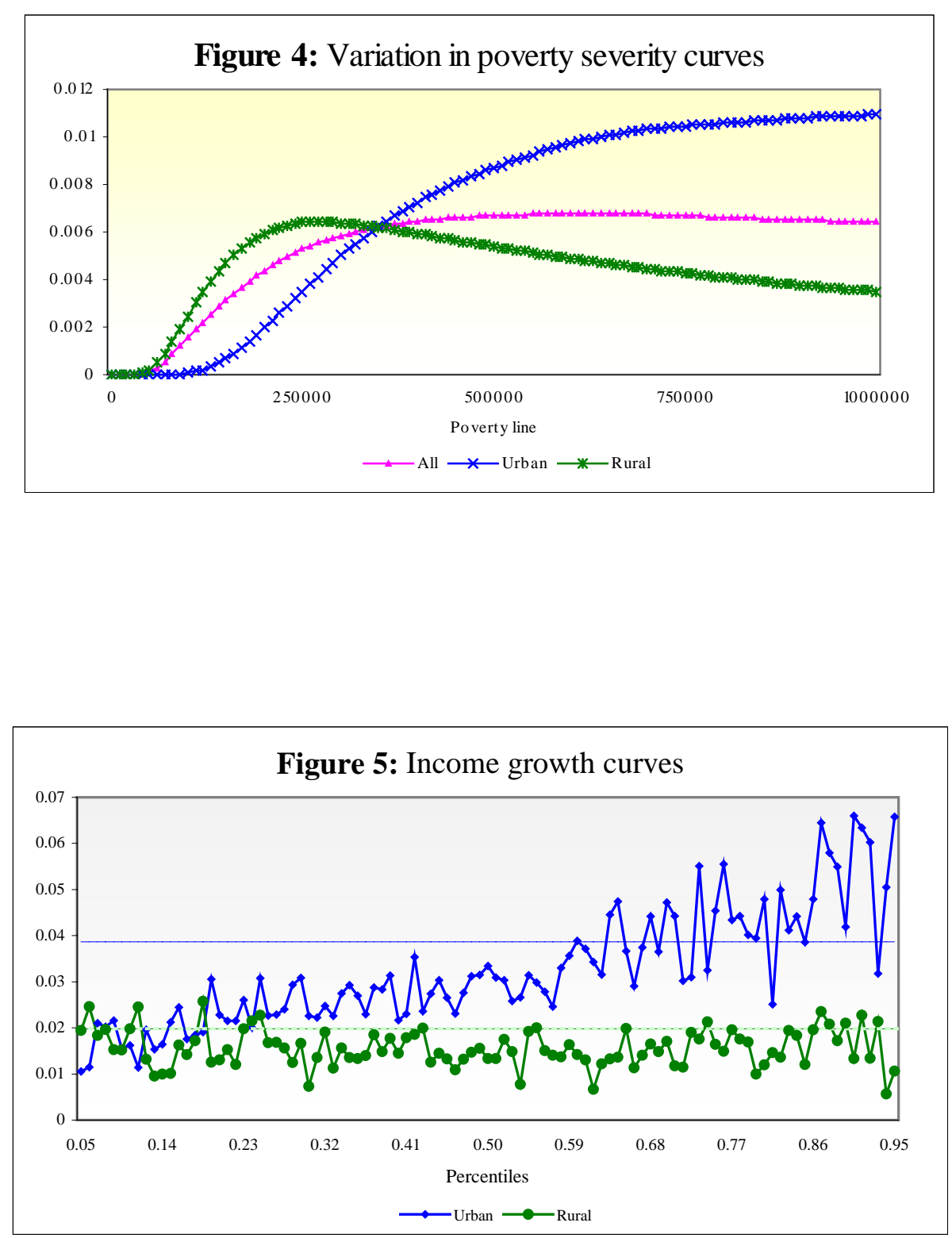


\section{REFERENCES}

Abbink G. A., Braber, M. C., and Cohen, S. I. (1995), A SAM-CGE demonstration model for Indonesia: A Static and Dynamic specifications and experiments. International Economic Journal, 9 (3): 15-33.

Annabi, N. Khondker, B. Raihan, S. Cockburn, J And Decaluwé B. (2005), Implications of WTO Agreements and Domestic Trade Policy Reforms for Poverty in Bangladesh: Short vs. Long Run Impacts. Chapter 15 in Putting Development Back into the Doha Agenda: Poverty Impacts of a WTO Agreement, Thomas W. Hertel and L. Alan Winters (eds.) forthcoming from the World Bank, Washington, DC.

Annabi, N., Cockburn, J. and Decaluwé, B. (2004), A Sequential Dynamic CGE Model for Poverty Analysis, mimeo, CIRPEE-PEP, Université Laval.

Bhagwati, J. and Srinivasan, T. N. (2002), Trade and Poverty in the Poor Countries. The American Economic Review, 92 (2): 180-183.

Boccanfuso, D. and Kaboré S. (2003), Croissance, inégalité et pauvreté dans les années 1990 au Burkina Faso et au Sénégal. Paper presented at Journées scientifiques du Réseau "Analyse économique et développement" Marrakech, Maroc.

Bourguignon, F., Branson, W. H. and J. de Melo. 1989. Macroeconomic Adjustment and Income Distribution: A Macro-Micro Simulation Model. OECD, Technical Paper No.1.

Bourguignon, F., and Pereira da Silva, L. A. (2003), The Impact of Economic Policies on Poverty and Income Distribution: Evaluation Techniques and Tools. Washington, D.C.: The World Bank and Oxford University Press.

Cockburn, J. (2001), Trade Liberalisation and Poverty in Nepal: A Computable General Equilibrium Microsimulation Analysis. Cahier de recherche 01-18, CREFA, Université Laval, Quebec.

Cogneau, D. Robillard, A. S. (2000), Growth, Income Distribution and Poverty in Madagascar: Learning from a Microsimulation Model in a General Equilibrium Framework. Trade and Macroeconomic Division, International Food Policy Research (IFPRI), TMD Discussion papers no 61.

Datt, G. and Ravallion, M. (1992), Growth and Redistribution Components of Changes in Poverty Measures: A Decomposition with Applications to Brazil and India in 1980s. Journal of Development Economics, 38: 275-295. 
Davies, J. (2003), Microsimulation, CGE and Macro Modelling for Transition and Developing Economies. mimeo, University of Western Ontario.

Decaluwé B., Patry, A. Savard, L. and E. Thorbecke. (1999), Poverty Analysis within a General Equilibrium Framework. Cahier de recherche 99-09, CREFA, Université Laval, Quebec.

Decaluwé, B., Dumont, J-C. and Savard, L. (1999), Measuring Poverty and Inequality in Computable General Equilibrium Model, Cahier de recherche 99-26, CREFA, Université Laval, Quebec.

Duclos, J-Y, Araar, A. and Fortin, C. (2004), DAD: A Software for Distributive Analysis/ Analyse Distributive. CIRPEE, Université Laval and PEP Network. http://www.pep-net.org

Duclos, J-Y and Araar, A. (2004), Poverty and Equity Measurement, Policy and Estimation with DAD. CIRPEE, Université Laval, Quebec.

Foster, J.E., Greer, J. and Thorbecke, E. (1984), A Class of Decomposable Poverty Measures. Econometrica, 52: 761-776.

Hertel, T. W. and Reimer, J. J. (2004), Predicting the Poverty Impacts of Trade Liberalization: A Survey. World Bank Policy Research Working Paper 3444.

Jung, H.S. and Thorbecke, E. (2003), The Impact of Public Education Expenditure on Human Capital, Growth, and Poverty in Tanzania and Zambia: A General Equilibrium Approach. Journal of Policy Modeling. 25: 701-725.

Kakwani, N. (1997), On Measuring Growth and Inequality Components of Changes in Poverty with Application to Thailand. Discussion paper 97/16, The University of New South Wales.

Kakwani, N. and Pernia, E. M. (2000), What is Pro-poor Growth? Asian Development Review, 18: 1-16.

Ravallion, M., Chen, S. (2003), Measuring pro-poor growth, Economics Letters, 78, 93:99.

Robilliard AS. and Robinson S. (2003), Reconciling Household Surveys and National Accounts Data Using a Cross Entropy Estimation Method. Review of Income and Wealth. 49, No 3: 395-406.

Shorrocks, A. F. (1999), Decomposition Procedures for Distributional Analysis: A Unified Framework Based on the Shapley Value. Department of Economics, University of Essex. 
Van der Mensbrugghe, D. (2003), LINKAGE. Technical Reference Document: The World Bank: Washington DC.

Winters, A. L., Mcculloch, N. and Mckay, A. (2004), Trade Liberalization and Poverty: The Evidence So Far. Journal of Economic Literature, vol. XLII: 72-115. 


\section{AnNeX}

\section{MODEL EQUATIONS}

\section{Production}

$$
X S_{j}=\min \left[\frac{C I_{j}}{i o_{j}}, \frac{V A_{j}}{v_{j}}\right]
$$

$$
V A_{\text {nag }}=A_{\text {nag }}^{K L}\left[\alpha_{\text {nag }}^{K L} L D_{\text {nag }}^{-\rho_{\text {gag }}^{K L}}+\left(1-\alpha_{\text {nag }}^{K L}\right) K D_{\text {nag }}^{-\rho_{\text {nag }}^{K L}}\right]^{-1 / \rho_{\text {nag }}^{K L}}
$$

$$
V A_{A G R}=A_{t r}^{C L}\left[\alpha^{C L} C F^{-\rho^{C L}}+\left(1-\alpha^{C L}\right) L a n d^{-\rho^{C L}}\right]^{-1 / \rho^{C L}}
$$

$$
C F=A_{a g r}^{K L}\left[\alpha_{a g r}^{K L} L D_{a g r}^{-\rho_{a g r}}+\left(1-\alpha_{a g r}^{K L}\right) K D_{a g r}^{-\rho_{a g r}^{K L}}\right]^{-1 / \rho_{a g r}^{K L}}
$$

$$
V A_{n t r}=L D_{n t r}
$$

$$
C I_{j}=i o_{j} X S_{j}
$$

$$
D I_{t r, j}=a i j_{t r, j} C I_{j}
$$

$$
\text { Land }=\left(\frac{1-\alpha^{C L}}{\alpha^{C L}}\right)^{\sigma^{C L}}\left(\frac{r c}{r l}\right)^{\sigma^{C L}} C F
$$

$$
L D_{t r}=\left(\frac{\alpha_{t r}^{K L}}{1-\alpha_{t r}^{K L}}\right)^{\sigma_{t r}^{K L}}\left(\frac{r_{t r}}{w}\right)^{\sigma_{t r}^{K L}} K D_{t r}
$$

$$
L D_{N T R}=\frac{P_{N T R} X S_{N T R}-\sum_{t r} P D_{t r} D I_{t r, N T R}}{w}
$$




\section{Income and savings}

(11)

$$
Y H_{h}=\lambda_{h}^{W} \cdot w \sum_{j} L D_{j}+\lambda_{h}^{R} \sum_{t r} r_{t r} K D_{t r}+\lambda_{h}^{L} \cdot r l \cdot \text { Land }
$$

+ Pindex $\cdot T G_{h}+D I V_{h}$

$$
Y D H_{h}=Y H_{h}-D T H_{h}
$$

$$
\begin{gathered}
S H_{h}=\psi_{h} \cdot Y D H_{h}+I H S_{h} \\
\text { (14) } \quad Y F=\lambda^{R F} \sum_{t r} r_{t r} K D_{t r}+\lambda^{L F} \cdot r l \cdot L A N D \\
\text { (15) } \quad Y F=Y F-\sum_{h} D I V_{h}-e \cdot D I V^{R O W}-D T F \\
\text { (16) } \quad \sum_{t r} T I_{t r}+\sum_{t r} T I E_{t r}+\sum_{t r} T I M_{t r}+\sum_{h} D T H_{h}+D T F \\
\text { (17) } \quad T I_{t r}=t x_{t r}\left(P_{t r} X S_{t r}-P E_{t r} E X_{t r}\right)+t x_{t r}\left(1+t m_{t r}\right) e P W M_{t r} M_{t r} \\
\text { (18) } \quad T I M_{t r}=t m_{t r} e P W M_{t r} M_{t r} \\
\text { (19) } T G_{h}-P i n v \cdot I G \\
\text { (20) } \quad D T E_{t r}=t e_{t r} P E_{t r} E X_{t r}=t y h_{h} Y H_{h} \\
\text { (21) } \quad D T F=t y f \cdot Y F \\
\text { (22) }
\end{gathered}
$$

\section{Demand}

$$
\begin{gathered}
C T H_{h}=Y D H_{h}-S H_{h} \\
P C_{t r} \cdot C_{t r, h}=\gamma_{t r, h} \cdot C T H_{h} \\
G=X S_{n t r} P_{n t r}-P i n v \cdot I G
\end{gathered}
$$




$$
\begin{gathered}
I N V_{t r}=\frac{\mu_{t r} I T}{P C_{t r}} \\
D I T_{t r}=\sum_{j} D I_{j}
\end{gathered}
$$

\section{Prices}

$$
P V_{j}=\frac{P_{j} X S_{j}-\sum_{t r} P C_{t r} D I_{t r, j}}{V A_{j}}
$$

$$
\begin{gathered}
r_{n a g}=\frac{P V_{n a g} V A_{n a g}-w L D_{n a g}}{K D_{n a g}} \\
r_{A G R}=\frac{r C \cdot C F-w L D_{A G R}}{K D_{A G R}} \\
r c=\frac{P V_{A G R} V A_{A G R}-r l \cdot L a n d}{C F} \\
P D_{t r}=\left(1+t x_{t r}\right) P L_{t r} \\
P M_{t r}=\left(1+t x_{t r}\right)\left(1+t m_{t r}\right) e \cdot P W M_{t r} \\
P E_{t r}=\frac{e \times P E-f o b_{t r}}{1+t e_{t r}} \\
P C_{t r} Q_{t r}=P D_{t r} D_{t r}+P M_{t r} M_{t r} \\
P_{t r} X S_{t r}=P L_{t r} D_{t r}+P E_{t r} E X_{t r} \\
\text { Pinv }=\prod\left(\frac{P C_{t r}}{\mu_{t r}}\right)^{\mu_{t r}} \\
\text { Pindex }=\sum_{i} \delta_{i} P V_{i}
\end{gathered}
$$




\section{International Trade}

$$
\begin{aligned}
& X S_{t r}=B_{t r}^{E}\left[\beta_{t r}^{E} E X_{t r}^{\kappa_{r}^{E}}+\left(1-\beta_{t r}^{E}\right) D_{t r}^{\kappa_{t r}^{E}}\right] \frac{1}{\kappa_{t r}^{E}} \\
& E X_{t r}=\left[\left(\frac{P E_{t r}}{P L_{t r}}\right)\left(\frac{1-\beta_{t r}^{E}}{\beta_{t r}^{E}}\right)\right]^{\tau_{r}^{E}} D_{t r}
\end{aligned}
$$

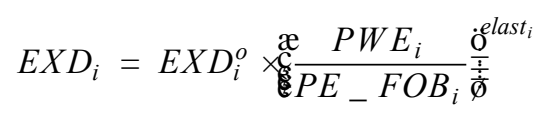

$$
\begin{aligned}
& Q_{t r}=A_{t r}^{M}\left[\alpha_{t r}^{M} M_{t r}^{-\rho_{t r}^{M}}+\left(1-\alpha_{t r}^{M}\right) D_{t r}^{-\rho_{t r}^{M}}\right]^{\frac{-1}{\rho_{t r}}} \\
& M_{t r}=\left[\left(\frac{P D_{t r}}{P M_{t r}}\right)\left(\frac{\alpha_{t r}^{M}}{1-\alpha_{t r}^{M}}\right)\right]^{\sigma_{r t}^{M}} D_{t r} \\
& C A B=\sum_{t r} P W M_{t r} M_{t r}+\lambda^{R O W} \sum_{t r} r_{t r} K D_{t r} / e+\lambda^{L R O W} r l \cdot \text { Land } / e \\
& +D I V^{R O W}-\sum_{t r} P E_{-} f o b_{t r} E X_{t r}
\end{aligned}
$$

\section{Equilibrium}

$$
Q_{i}=D I T_{i}+\underset{h}{\AA_{h}} C_{i, h}+I N V_{i}+D s t k_{i}
$$

$$
\begin{aligned}
& E X_{i}=E X D_{i} \\
& L S=\sum_{j} L D_{j} \\
& I T+\underset{i}{\mathrm{a}} P C_{i} D s t k_{i}=\mathrm{a}_{h} S H_{h}+S F+S G+e \times C A B
\end{aligned}
$$

\section{Dynamic Equations}

$$
\begin{gathered}
K D_{t r, t+1}=(1-\delta) K D_{t r, t}+I n d_{t r, t} \\
L S_{t+1}=(1+n g) \cdot L S_{t}
\end{gathered}
$$


(51)

$$
\begin{aligned}
& \frac{\operatorname{Ind}_{t r, t}}{K D_{t r, t}}=\phi_{t r} \cdot\left(\frac{R_{t r, t}}{U_{t}}\right)^{2} \\
& U_{t}=\operatorname{Pinv}_{t} \cdot(i r+\delta) \\
& I T_{t}=P i n v_{t} \cdot\left(\sum_{t r} I n d_{t r, t}+I G\right) \\
& T G_{t+1}=(1+n g) \times T G_{t} \\
& I G_{t+1}=(1+n g) \times I G_{t} \\
& X S_{n t r, t+1}=(1+n g) \times X S_{n t r, t} \\
& D I V_{t+1}=(1+n g) \times D I V_{t} \\
& D I V_{-} R O W_{t+1}=(1+n g) \times D I V_{-} R O W_{t} \\
& T W H_{t+1}=(1+n g) \times T W H_{t} \\
& T H_{h, h j, t+1}=(1+n g) \times T H_{h, h j, t} \\
& E X D_{t+1}^{o}=(1+n g) \times E X D_{t}^{o} \\
& \text { Land }_{t+1}=(1+n g) \times \text { Land }_{t}
\end{aligned}
$$

\section{Endogenous variables}

$C_{t r, h}: \quad \quad$ Household $h$ 's consumption of good $\operatorname{tr}$ (volume)

$C F$ : $\quad$ Composite agricultural capital-labour factor (volume)

$C I_{j}$ : $\quad$ Total intermediate consumption of activity $j$ (volume)

$\mathrm{CTH}_{h}$ : $\quad$ Household $h$ 's total consumption (value)

$D_{t r}$ : $\quad$ Demand for domestic good $\operatorname{tr}$ (volume)

$D I_{t r, j}$ : $\quad$ Intermediate consumption of good $t r$ in activity $j$ (volume)

$D I T_{t r}$ : $\quad$ Intermediate demand for good $t r$ (volume)

DTF : $\quad$ Receipts from direct taxation on firms' income

$\mathrm{DTH}_{h}$ : $\quad$ Receipts from direct taxation on household $h$ 's income 


$\begin{array}{ll}e: & \text { Nominal exchange rate } \\ E X_{t r}: & \text { Exports in good } t r \text { (volume) } \\ G: & \text { Public expenditures } \\ I N V_{t r}: & \text { Investment demand for good } t r \text { (volume) } \\ I T: & \text { Total investment } \\ L D_{j}: & \text { Activity } j \text { demand for labour (volume) } \\ M_{t r}: & \text { Imports in good } t r \text { (volume) } \\ P_{i}: & \text { Producer price of good } i \\ P C_{t r}: & \text { Consumer price of composite good } t r \\ P D_{t r}: & \text { Domestic price of good } t r \text { including taxes } \\ P E_{t r}: & \text { Domestic price of exported good } t r \\ P i n d e x: & \text { GDP deflator } \\ P i n v: & \text { Price index of investment } \\ P L_{t r}: & \text { Domestic price of good } t r \text { (excluding taxes) } \\ P M_{t r}: & \text { Domestic price of imported good } t r \\ P V_{j}: & \text { Value added price for activity } j \\ Q_{t r}: & \text { Demand for composite good } t r \text { (volume) } \\ r_{t r}: & \text { Rate of return to capital in activity } t r \\ r l: & \text { Rate of return to agricultural land } \\ r c: & \text { Rate of return to composite factor } \\ S F: & \text { Firms' savings } \\ S G: & \text { Gousehold } h \text { 's income } \\ S H_{h}: & \text { Government's savings } \\ T I_{t r}: & \text { Household } h \text { 's savings } \\ T I E_{t r}: & \text { Receipts from indirect tax on } t r \\ T I M_{t r}: & \text { Receipts from tax on export } t r \\ V A_{j}: & \text { Receipts from import duties } t r \\ w: & \text { Value added for activity } j \text { (volume) } \\ X S_{t r}: & \text { Wage rate } \\ Y D H_{h}: & \text { Output of activity } t r \text { (volume) } \\ Y F: & h H_{h}:\end{array}$


$K D_{t r}$ : $\quad$ Demand for capital in activity $\operatorname{tr}$ (volume)

$C A B$ : $\quad$ Current account balance

Ind $_{t r, t}$ : $\quad$ Demand for capital in activity $\operatorname{tr}$ (volume)

$U_{t}: \quad$ Capital user cost

\section{Exogenous variables}

$D I V_{h}$ : $\quad$ Dividends paid to household $h$

$D I V^{R O W}$ : $\quad$ Dividends paid to the rest of the World

Land : $\quad$ Land supply (volume)

$P W E_{t r}$ : $\quad$ World price of export $t r$

$P W M_{t r}$ : $\quad$ World price of import $t r$

$T G_{h}$ : $\quad$ Public transfers to household $h$

$X S_{N T R}$ : $\quad$ Output of activity NTR (volume)

\section{Parameters}

\section{Production functions}

$A_{j}: \quad$ Scale coefficient (Cobb-Douglas production function)

$a i j_{t r, j}$ : $\quad$ Input-output coefficient

$\alpha_{j}: \quad$ Elasticity (Cobb-Douglas production function)

$i o_{j}$ : $\quad$ Technical coefficient (Leontief production function)

$v_{j}: \quad$ Technical coefficient (Leontief production function)

\section{CES function between capital and labour}

$A_{t r}^{K L}: \quad \quad$ Scale coefficient

$\alpha_{t r}^{K L}: \quad$ Share parameter

$\rho_{t r}^{K L}: \quad \quad$ Substitution parameter

$\sigma_{t r}^{K L}: \quad$ Substitution elasticity 


\section{CES function between composite factor and land}

$\begin{array}{ll}A_{t r}^{C L}: & \text { Scale coefficient } \\ \alpha_{t r}^{C L}: & \text { Share parameter } \\ \rho_{t r}^{C L}: & \text { Substitution parameter } \\ \sigma_{t r}^{C L}: & \text { Substitution elasticity }\end{array}$

CES function between imports and domestic production

$\begin{array}{ll}A_{t r}^{M}: & \text { Scale coefficient } \\ \alpha_{t r}^{M}: & \text { Share parameter } \\ \rho_{t r}^{M}: & \text { Substitution parameter } \\ \sigma_{t r}^{M}: & \text { Substitution elasticity }\end{array}$

\section{CET function between domestic production and exports}

$\begin{array}{ll}B_{t r}^{E}: & \text { Scale coefficient } \\ \beta_{t r}^{E}: & \text { Share parameter } \\ \kappa_{t r}^{E}: & \text { Transformation parameter } \\ \tau_{t r}^{E}: & \text { Transformation elasticity }\end{array}$

\section{$C-D$ consumption function}

$\gamma_{t r, h}: \quad$ Marginal share of good $t r$

\section{Tax rates}

$\begin{array}{ll}t e_{t r}: & \text { Tax on exports } t r \\ t m_{t r}: & \text { Import duties on good } t r \\ t x_{t r}: & \text { Tax rate on good } t r \\ t y h_{h}: & \text { Direct tax rate on household } h \text { 's income } \\ t y f: & \text { Direct tax rate on firms' income }\end{array}$

\section{Other parameters}

$\delta_{j}: \quad$ Share of activity $j$ in total value added

$\lambda_{h}^{L}$ : $\quad$ Share of land income received by household $h$ 


$\begin{array}{ll}\lambda^{L F}: & \text { Share of land income received by firms } \\ \lambda^{L R O W}: & \text { Share of land income received by foreigners } \\ \lambda_{h}^{R}: & \text { Share of capital income received by household } h \\ \lambda^{R F}: & \text { Share of capital income received by firms } \\ \lambda^{R O W}: & \text { Share of capital income received by foreigners } \\ \lambda_{h}^{W}: & \text { Share of labour income received by household } h \\ \psi_{h}: & \text { Propensity to save } \\ \mu_{t r}: & \text { Share of the value of good } t r \text { in total investment } \\ n g: & \text { Population growth rate } \\ \delta: & \text { Capital depreciation rate } \\ \phi_{t r}: & \text { Scale parameter in the investment demand function } \\ i r: & \text { Real interest rate }\end{array}$

\section{Sets}

$\begin{array}{ll}i, j \in I=\{A G R, I N D, S E R, N T R\} & \text { All activities and goods (AGR: agriculture, IND: } \\ & \begin{array}{l}\text { industry, } S E R \text { : services, NTR: non-tradable } \\ \text { services) }\end{array} \\ t r \in T R=\{A G R, I N D, S E R\} & \text { Tradable activities and goods } \\ n a g \in N A G=\{I N D, S E R\} & \text { Non-agricultural Tradable activities and goods } \\ h \in H=\{h 1, \ldots, h 3278\} & \text { Households } \\ t, t \in T=\{1996, \cdots, 2015\} & \text { Time horizon }\end{array}$




\section{LIST OF WORKING PAPERS RELEASED BY CEPII ${ }^{12}$}

No

Title

2005-06 Migration, Trade and Wages

2005-05 Institutional Determinants of Foreign Investment

2005-04 L'économie indienne : changements structurels et perspectives à long terme

2005-03 Programme de travail du CEPII pour 2005

2005-02 Market Access in Global and Regional Trade

2005-01 Real Equilibrium Exchange Rate in China

2004-22 A Consistent, ad-valorem Equivalent Measure of Applied Protection Across the World: The MacMapHS6 Database

2004-21 IMF in Theory: Sovereign Debts, Judicialisation and Multilateralism

2004-20 The Impact of Multilateral Liberalisation on European Regions: a CGE Assessment

2004-19 La compétitivité de l'agriculture et des industries agroalimentaires dans le Mercosur et l'Union européenne dans une perspective de libéralisation commerciale

2004-18 Multilateral Agricultural Trade Liberalization: The Contrasting Fortunes of Developinc Countries in the Doha Round

2004-17 UK in or UK out? A Common Cycle Analysis between the UK and the Euro Zone

\section{Authors}

A. Hijzen \& P. Wright

A. Bénassy-Quéré, M. Coupet \& T. Mayer

S. Chauvin \& F. Lemoine

T. Mayer \& S. Zignago

V. Coudert \& C. Couharde

A. Bouët, Y. Decreux, L. Fontagné, S. Jean \& D. Laborde J. Sgard

S. Jean \& D. Laborde

N. Mulder, A. Vialou, B. David, M. Rodriguez \& M. Castilho A. Bouët, J.C. Bureau, Y. Decreux \& S. Jean

J. Garnier

\footnotetext{
${ }^{12}$ Working papers are circulated free of charge as far as stocks are available; thank you to send your request to CEPII, Sylvie Hurion, 9, rue Georges-Pitard, 75015 Paris, or by fax : (33) 0153685504 or by e-mail Hurion@cepii.fr. Also available on: ॥www.cepii.fr. Working papers with* are out of print. They can nevertheless be consulted and downloaded from this website.

${ }^{12}$ Les documents de travail sont diffusés gratuitement sur demande dans la mesure des stocks disponibles. Merci d'adresser votre demande au CEPII, Sylvie Hurion, 9, rue Georges-Pitard, 75015 Paris, ou par fax : (33) 0153685504 ou par e-mail Hurion@cepii.fr. Egalement disponibles sur : ॥www.cepii.fr. Les documents de travail comportant * sont épuisés. Ils sont toutefois consultable sur le web CEPII.
} 
2004-16 Regionalism and the Regionalisation of International Trade

2004-15 The Stock-Flow Approach to the Real Exchange Rate of CEE Transition Economies

2004-14 Vieillissement démographique, épargne et retraite : une analyse à l'aide d'un modèle d'équilibre général à agents hétérogènes

2004-13 Burden Sharing and Exchange-Rate Misalignments within the Group of Twenty

2004-12 Regulation and Wage Premia

2004-11 The Efficiency of Fiscal Policies: a Survey of the Literature

2004-10 La réforme du marché du travail en Allemagne : les enseignements d'une maquette

2004-09 Typologie et équivalence des systèmes de retraites

2004-08 South - South Trade: Geography Matters

2004-07 Current Accounts Dynamics in New EU Members: Sustainability and Policy Issues

2004-06 Incertitude radicale et choix du modèle

2004-05 Does Exchange Rate Regime Explain Differences in Economic Results for Asian Countries?

2004-04 Trade in the Triad: How Easy is the Access to Large Markets?

2004-03 Programme de travail du CEPII pour 2004

2004-02 Technology Differences, Institutions and Economic Growth: a Conditional Conditional Convergence

2004-01 Croissance et régimes d'investissement

2003-22 A New Look at the Feldstein-Horioka Puzzle using a Integrated Panel

2003-21 Trade Linkages and Exchange Rates in Asia:The Role of China
G. Gaulier, S. Jean \&

D. Ünal-Kesenci

B. Egert,

A. Lahrècche-Révil \&

K. Lommatzsch

C. Bac \& J. Chateau

A. Bénassy-Quéré,

P. Duran-Vigneron,

A. Lahrèche-Révil \&

V. Mignon

S. Jean \& G. Nicoletti

S. Capet

S. Capet

P. Villa

S. Coulibaly \&

L. Fontagné

P. Zanghieri

P. Villa

V. Coudert \&

M. Dubert

L. Fontagné, T. Mayer

\& S. Zignago

H. Boulhol

P. Villa

A. Banerjee \&

P. Zanghieri

A. Bénassy-Quéré \&

A. Lahrèche-Révil 
2003-20 Economic Implications of Trade Liberalization

J. Francois, Under the Doha Round

H. van Meijl \&

F. van Tongeren

2003-19 Methodological Tools for SIA - Report of the CEPII Worshop held on 7-8 November 2002 in Brussels

2003-18 Order Flows, Delta Hedging and Exchange Rate Dynamics

2003-17 Tax Competition and Foreign Direct Investment

B. Rzepkowski

A. Bénassy-Quéré,

L. Fontagné \&

A. Lahrèche-Révil

F. Lemoine \&

2003-16 Commerce et transfert de technologies: les cas comparés de la Turquie, de l'Inde et de la Chine

D. Ünal-Kesenci

2003-15 The Empirics of Agglomeration and Trade

K. Head \& T. Mayer

2003-14 Notional Defined Contribution: A Comparison of the French and German Point Systems

2003-13 How Different is Eastern Europe? Structure and Determinants of Location Choices by French Firms in Eastern and Western Europe

2003-12 Market Access Liberalisation in the Doha Round: Scenarios and Assessment

F. Legros

A.C. Disdier \&

T. Mayer

L. Fontagné,

J.L. Guérin \& S. Jean

2003-11 On the Adequacy of Monetary Arrangements in SubSaharian Africa

A. Bénassy-Quéré \& M. Coupet

2003-10 The Impact of EU Enlargement on Member States: a CGE Approach

H. Bchir, L. Fontagné \& P. Zanghieri

S. Chauvin \& F. Lemoine Specialisations and Technology Niches

M. Beine,

2003-08 Imitation Amongst Exchange-Rate Forecasters: Evidence from Survey Data

A. Bénassy-Quéré \&

H. Colas

2003-07 Le Currency Board à travers l'expérience de l'Argentine

2003-06 Trade and Convergence: Revisiting Ben-Davil

G. Gaulier

2003-05 Estimating the Fundamental Equilibrium Exchange Rate of Central and Eastern European Countries the EMU Enlargement Perspective

B. Egert \&

A. Lahrèche-Révil 


\section{CEPII \\ DOCUMENTS DE TRAVAIL / WORKING PAPERS}

Si vous souhaitez recevoir des Documents de travail, merci de remplir le coupon-réponse ci-joint et de le retourner à :

Should you wish to receive copies of the CEPII's Working papers, just fill the reply card and return it to:

Sylvie HURION - Publications

CEPII - 9, rue Georges-Pitard - 75740 Paris - Fax : (33) 1.53.68.55.04

M./Mme / Mr./Mrs

Nom-Prénom / Name-First name....

Titre / Title

Service / Department

Organisme / Organisation

Adresse / Address.

Ville \& CP / City \& post code.

Pays / Country..... Tél.

Désire recevoir les Document de travail du CEPII $n^{\circ}$ :

Wish to receive the CEPII's Working Papers No: 